ROCZNIKI HUMANISTYCZNE

Tom LXIX, zeszyt $12-2021$

DOI: https://doi.org/10.18290/rh216912-5

BOGUMIŁA MIKA

\title{
IV KONCERT FORTEPIANOWY LUDWIGA VAN BEETHOVENA W ODCZYTANIU MIKROHISTORYCZNYM
}

IV Koncert fortepianowy (op. 58) Ludwiga van Beethovena wpisuje się w obręb tzw. kanonicznych dzieł muzyki poważnej. Powstał w 1806 roku, wraz z takimi innymi kompozycjami, jak trzy kwartety smyczkowe Razumowskiego (op. 59), IV Symfonia (op. 60), Koncert skrzypcowy (op. 61), 32 wariacje c-moll na temat wtasny (WoO 80) i Uwertura Coriolan (op. 62). Choć jest dziełem znakomicie znanym i przebadanym, nadal inspiruje muzykologów do nowych sposobów interpretacji. Jednym z nich zdaje się być podejście mikrohistoryczne.

Niniejszy artykuł stanowi próbę wykazania korzyści płynących z odczytania IV Koncertu fortepianowego Beethovena $\mathrm{z}$ zastosowaniem mikrohistorii stosunkowo nowej, na gruncie muzykologii, perspektywy badawczej. Bazą dla rozważań stała się praca Marka Ferraguto Beethoven 1806 (2019).

Artykuł rozpoczyna krótka refleksja na temat przydatności i dotychczasowej obecności mikrohistorii w badaniach muzykologicznych. Kolejne fragmenty tekstu dedykowane są możliwościom, jakich dostarcza zastosowanie mikrohistorii $\mathrm{w}$ inwestygacji twórczości Beethovena. Prezentacja rezultatów badań Ferraguto - skoncentrowanych wokół kilku wyodrębnionych przez amerykańskiego naukowca kategorii analitycznych w odniesieniu do IV Koncertu fortepianowego - stanowić będzie główną część niniejszych rozważań.

Przed przystąpieniem do zasadniczej tematyki artykułu warto jednak przypomnieć kilka podstawowych informacji dotyczących tytułowej kompozycji.

Dr hab. BogumiŁa MIKA, prof. UŚ - Dyrektor Instytutu Nauk o Sztuce, Uniwersytet Śląski w Katowicach; adres do korespondencji: ul. Bankowa 11, 40-007 Katowice; e-mail: bogumila.mika@us.edu.pl; ORCID: https://orcid.org/0000-0002-6709-1109.

Dr. Hab. Bogumita MiKa, Associate Professor at the University of Silesia in Katowice, Director of the Institute of Art Studies; address for correspondence: ul. Bankowa 11, 40-007 Katowice, Poland; e-mail: bogumila.mika@us.edu.pl; ORCID: https://orcid.org/0000-0002-6709-1109. 
Beethoven dedykował ją swemu mecenasowi, uczniowi i przyjacielowi Arcyksięciu Rudolfowi Johannowi Habsburgowi (Steinberg 64). Utwór po raz pierwszy został wykonany w marcu $1807 \mathrm{w}$ Wiedniu w pałacu innego mecenasa - księcia Franza Josepha von Lobkowitza, w tzw. „Eroica-Saal” (Jander 200). Zabrzmiała wówczas także Uwertura Coriolan (Kinderman 144).

Premiera publiczna miała miejsce 22 grudnia 1808 roku w Theater-an-derWien podczas słynnej „Akademii” - kompozytorskiego koncertu Beethovena, który należy uznać za swoisty maraton. W programie znalazły się bowiem obok IV Koncertu fortepianowego dwie symfonie: Piąta i Szósta, Fantazja choratowa c-moll op. 80 (na fortepian solo, orkiestrę i chór), fragmenty (trzy pierwsze części) $M s z y$ C-dur op. 86, improwizacje fortepianowe oraz aria koncertowa Ah! perfido - Per pieta z 1796 roku (Steinberg 64). W IV Koncercie Beethoven wcielił się w rolę podwójną: solisty i dyrygenta. Był to jego ostatni solowy występ w charakterze pianisty, niestety przyjęty dość chłodno przez wiedeńską publiczność. Cały zaś wieczór koncertowy można uznać za swoistą katastrofę. Niedostatecznie przygotowana orkiestra nie była w stanie sprostać ani wymogom samej muzyki (w większości nowej) ani kapelmistrzowskim oczekiwaniom Beethovena. Lodowata temperatura panująca w nieogrzanym teatrze dawała się we znaki zarówno wykonawcom, jak i publiczności.

Niemiecki kompozytor i krytyk muzyczny, uczestnik premierowego koncertu, Joseph Friedrich Reichardt donosił, iż „Z wdzięcznością przyjął skierowane przez Księcia Lobkowitza zaproszenie do jego loży" (Forbes 448), w której następnie przez cztery godziny (od 18.30 do 22.20) „W lodowatym zimnie doświadczał nadmiaru dobrobytu" (448).

Komentarze opublikowane po „Akademii” zauważały, że program koncertu był za długi, w sali było za zimno, a dwukrotne rozpoczęcie wykonania Fantazji chorałowej okazało się zabiegiem koniecznym, acz żenującym (Skowroneck 2010, 148). „Akademia” z wielu powodów nie usatysfakcjonowała również Reichardta, ale o IV koncercie fortepianowym pisał on pozytywnie. Oceniał: „Nowy koncert na fortepian, potwornie trudny, Beethoven wykonał zadziwiająco dobrze w najszybszym możliwym tempie" (Strunk 738). Drugą część utworu nazwał ,arcydziełem pięknej podtrzymywanej melodii, [które] Beethoven rzeczywiście wyśpiewał na swoim instrumencie z głęboką melancholią" (738). Uczeń Beethovena, Carl Czerny opisywał otwierającą część koncertu jako „spokojną, pełną prostoty i wdzięku, niemal w stylu pastoralnym..." (Czerny 109). Samo premierowe Beethovenowskie wykonanie dzieła uznał za bardzo żartobliwe i zawierające wiele wirtuozowskich, kapryśnych, a czasem dowcipnych wariantów partii fortepianu, „wpisanych przez 
kompozytora do poprawionej kopii rękopiśmiennej partytury, nie znajdujących się jednak jeszcze w żadnym drukowanym wydaniu" (Steinberg 64).

$I V$ koncert fortepianowy po swej wiedeńskiej premierze nie wybrzmiał już publicznie za życia Beethovena. Do repertuaru koncertowego przywrócił go dopiero w 1836 roku Feliks Mendelssohn. Obecnie należy do najczęściej wykonywanych dzieł literatury pianistycznej.

\section{MIKROHISTORIA W MUZYKOLOGII}

Mikrohistoria jest praktyką historiograficzną skoncentrowaną na opisie tego, co szczegółowe, partykularne, jednostkowe, niewielkie pod względem przestrzennym, ograniczone czasowo; dotykającą problemów życia codziennego i świadomości pojedynczych członków lokalnych wspólnot. Mikrohistoria stanowi więc przeciwieństwo makrohistorii.

Jako praktyka historiograficzna mikrohistoria zaistniała pod koniec lat 70 . i na początku lat 80 . XX wieku, wtedy też wydała swe klasyczne, najczęściej cytowane w minionym stuleciu dzieła autorstwa Carla Ginzburga (1976), Emmanuela Le Roy Laduriego (1975), Natalie Zemon Davis (1983), Roberta Darntona (1984) i Giovanniego Leviego (1985). Na teren muzykologii wkroczyła z pewnym opóźnieniem, bo na początku bieżącego stulecia. Doczekała się już jednak kilku prac o szczególnym znaczeniu poznawczym, takich, jak książka Marka Everista (2002) o czterech latach działalności paryskiego Teatru Odéon, 600-stronicowa monografia Tamary Levitz (2012), poświęcona zaledwie 55-minutowej melodramie Strawińskiego Perséphone z 1934 roku, tekst Petera J. Schmelza (2015) opisujący sposoby uczestnictwa muzyki w konflikcie zimnowojennym czy studium Marka Ferraguto (2019) o Beethovenie. W tej ostatniej pracy autor przypomina trzy cechy charakterystyczne dla strategii mikrohistorycznej, którymi są: analiza poszczególnych przypadków lub specyficznych okoliczności w miejsce badania rozwoju zjawiska na przełomie dekad czy stuleci; dowartościowanie „mikrobadania” w celu znalezienia odpowiedzi na „większe” pytania historyczne; oraz traktowanie osób historycznie istniejących jako ,świadomych aktorów” procesów historycznych (Ferraguto 3). 


\section{MUZYKA BEETHOVENA W ODCZYTANIU MIKROHISTORYCZNYM}

Refleksję nad pożytkami z zastosowania przez Ferraguto nowej perspektywy interpretacyjnej należy rozpocząć od uwagi, iż mikrohistoria rozprawia się z „romantycznym” odczytaniem życia i twórczości Beethovena, wiążącym dramatyczną walkę $z$ twórczym natchnieniem. A z tej to narracji - wyolbrzymionej po śmierci Twórcy z Bonn - wyłonił się promowany przez dziesięciolecia swoisty „mit Beethovena” (Knittel 121).

Mikrohistoria odsuwa na plan dalszy wpisanie badanego dzieła w konkretną fazę stylistyczną czy w dany etap twórczy kompozytora. Nie zajmują jej, ponad konieczną miarę, wszelkie analizy stylokrytyczne. Równocześnie dąży do pełnej interpretacji kompozycji przynależnych już często do muzycznego kanonu, do potwierdzenia ich wartości i wpisania w spójny, ukształtowany wcześniej, całościowy obraz twórczości.

Pomocną dla takich działań okazuje się być koncepcja mediacji, wypracowana na gruncie wzajemnych związków sztuki i społeczeństwa (Hennion 2003, Latour 2005), a także dążenie do zrozumienia muzyki w nowy, szerszy sposób, tj. w relacji do konkretnych osób, przedmiotów, miejsc i okoliczności życia twórcy. Kompozytor zwykle bywa bowiem zależny od zleceniodawców, wykonawców, wydawców, krytyki a nawet od samej publiczności. W refleksji nad muzyką uwzględnienia godny jest też historyczny, polityczny i kulturowy kontekst czasów, w których została powołana ona do życia.

Jakkolwiek w obrębie naukowej refleksji o sztuce dźwięku badania nad tekstem muzycznym i jego kontekstem oraz badania wymiaru estetycznego i wymiaru społecznego często uważane są za wzajemnie sprzeczne, a nawet za wykluczające się, to przecież jednak autonomia sztuki nie wyklucza jej kontekstu. Rita Felski (584) ujmuje to następująco:

Autonomia sztuki - jeśli przez autonomię rozumiemy jej odrębność i szczególność nie wyklucza powiązania, lecz jest właśnie powodem, dla którego powiązania są tworzone i podtrzymywane... Dzieła sztuki mogą przetrwać i rozwijać się jedynie poprzez zdobywanie przyjaciół, tworzenie sprzymierzeńców, przyciąganie uczniów, przywiązywanie się do, otwartych na nich, gospodarzy.

Mikrohistoria korzysta też z dokonań innych obszarów badawczych. W przypadku muzyki koncertującej Beethovena szczególnie przydatną okazuje się być badanie wykonań muzycznych (performance studies), dotąd wyraźnie pozostające na uboczu muzykologicznych poszukiwań (Madrid 2009). Dzięki takim zainteresowaniom uprzywilejowana zwykle w teoretycznych tekstach 
domena analityczna ustąpić może miejsca lokowaniu znaczenia w akcie „uprawiania muzyki jako spotkania międzyludzkiego" (Small 10).

Studia z zakresu wykonań muzycznych wprowadzają dodatkowy wymiar w badaniach nad sztuką dźwięku rozwijaną w obrębie rozmaitych praktyk kulturowych i społecznych. Poza pytaniem o to, jak procesy zachodzące w obrębie owych praktyk pomagają nam zrozumieć muzykę, można zapytać też o to, jak poprzez muzykę i różne jej rodzaje da się zrozumieć procesy zachodzące w obrębie owych praktyk.

Dlatego Ferraguto (9), analizujący instrumentalne kompozycje Beethovena, nie pyta o znaczenie samej muzyki, ale o znaczenie jej dla twórcy. Pyta, co muzyka uczyniła dla Beethovena w okresie, gdy ją tworzył, a szczególnie w jaki sposób pomogła mu negocjować pozycję społeczną w Wiedniu w czasach, gdy starał się on tam pozyskiwać środki do życia zarówno ze strony zleceniodawców, jak i muzycznego rynku. Ferraguto ma przy tym pełną świadomość, iż stawianie takich pytań wiąże się z dowartościowaniem wymiaru społecznego muzyki (autor skupia bowiem swą uwagę na interakcjach Beethovena z ludźmi, instrumentami, rynkami i ideami) kosztem pomijania jej znaczenia estetycznego, więc w rezultacie tego typu metodologia może wzbudzać krytykę.

Kolejne pytanie, jakie stawia sobie Ferraguto (10) brzmi: w jaki sposób kompozycje Beethovena nie tyle odzwierciedlają, co raczej tworzą to, co społeczne. Autor odwołuje się przy tym do idei Antoine Hennion, który podkreślając rolę sił pośredniczących zauważył, że artefakt nie jest kreowany wyłącznie przez samego artystę, lecz stanowi raczej formę „dzieła kolektywnego” (Hennion 7).

Perspektywa mikrohistoryczna zakłada, że każde dzieło może być badane w sposób indywidualny i historyczny zarazem. Nie oznacza to bynajmniej ignorowania rozważań dotyczących stylu kompozytorskiego czy fazy twórczej. Ale analiza każdej kompozycji w uwzględnieniem sieci jej powiązań umożliwia przesunięcie akcentu $\mathrm{z}$ koncepcji samego dzieła w stronę jego wyjątkowości i mediatorów, którzy pozwolili nadać mu finalny kształt.

W rozważaniach mikrohistorycznych Ferraguto wziął pod uwagę prywatne notatki Beethovena, jego korespondencję z wydawcami i mecenasami, pisma estetyczne, doniesienia prasowe, rozmaite warianty jego opublikowanych utworów. Analiza tych dokumentów pozwoliła odkryć, w jaki sposób kompozytor starał się uwzględniać w swej muzyce gusta amatorów i znawców, styl popularny i wyuczony, trendy koniunktury i pragnienie pozostania oryginalnym. 
W przypadku IV Koncertu fortepianowego Beethovena wykorzystanie metody mikrohistorycznej pozwoliło na wyodrębnienie i scharakteryzowanie kilku ważnych zagadnień. Są to m.in.: technika pianistyczna twórcy w powiązaniu z oczekiwaniami współczesnych mu słuchaczy, kategoria wirtuozostwa w kontekście ówczesnych debat estetycznych, artystyczna osobowość kompozytora oraz możliwości i ograniczenia instrumentu pozostającego do jego dyspozycji w procesie komponowania. Rezultaty badań Ferraguto postaram się teraz pokrótce omówić.

\section{TECHNIKA PIANISTYCZNA BEETHOVENA A OCZEKIWANIA WSPÓŁCZESNYCH MU SŁUCHACZY}

Ferrugato (47) zwraca uwagę, że Beethovenowi jako profesjonalnemu pianiście nieobce były popisy wirtuozowskie. Odbywał „pojedynki fortepianowe” z takimi muzykami, jak Abbé Gelinek w 1793, Joseph Wölffl w 1799 i Daniel Steibelt w 1800. Występy takie służyły demonstracji pomysłowości artystycznej i siły fizycznej Beethovena. Podczas popisów kompozytor mógł się wykazać również talentem improwizatorskim i umiejętnością budowania koncertowej dramaturgii. Zdolności pianistyczne okazywały się przydatne w procesie tworzenia koncertów instrumentalnych. Istotna była również świadomość oczekiwań samych odbiorców w odniesieniu do poziomu wirtuozostwa i stylu gry pianistów.

Jako kompozytor Beethoven zabiegał o powodzenie u słuchaczy i o uznanie dla swojej twórczości, któremu - jak się zdaje - mogło pomagać rozpowszechnianie partytur wydanych drukiem. Bliższa analiza ówczesnych praktyk społecznych i rynku odbiorców podważa jednak nieco, zdaniem Ferraguto (48), ową tezę. Bo dla kompozytora miary Beethovena, wydawanie drukiem koncertów nie było jednoznacznie korzystnym przedsięwzięciem. Opublikowana partytura ujawniała bowiem tajniki techniki pianistycznej twórcy, a te mogły odtąd już z łatwością znaleźć naśladowców wśród innych wirtuozów. Wobec takich zabiegów należało zatem zachować pewną ostrożność. Z drugiej jednak strony Beethoven miał świadomość, że rynek tego typu odbiorców jego muzyki był ograniczony, bowiem niewiele osób mogło pozwolić sobie (warsztatowo i materialnie) na wykonanie koncertu instrumentalnego. Jak większość kompozytorów-wirtuozów tamtych czasów, on także dążył „,do maksymalizacji swej międzynarodowej reputacji i dochodu" (McVeigh 597), czemu publikacja koncertów wyraźnie służyła, nawet jeśli łączyła się z ograniczeniem zawartych w nich trudności technicznych. 
Równocześnie jednak $I V$ Koncert fortepianowy stawia wyraźne wyzwania konwencjonalnemu pojęciu koncertu, jako nośnika wirtuozowskiego popisu. Choć bowiem wirtuozowska brawura była cechą pożądaną przez publiczność koncertową, to Beethoven znacząco ją tu ograniczył, wprowadzając w muzykę obszerne fragmenty liryczne, pełne spokoju i zadumy. Uczynił to świadomie, dając wyraz nie tyle kryzysowi stylu heroicznego swej muzyki, ile raczej wpisując się w podejmowaną przez ówczesną estetyką debatę na temat wirtuozostwa. A ta, jak dowodzi Ferraguto (49), zakładała, że koncerty instrumentalne nie powinny być traktowane wyłącznie jako widowiska pianistycznych możliwości, ale jako rodzaj wehikułu, za pośrednictwem którego sama koncepcja wirtuozostwa mogła być kontestowana.

\section{KATEGORIA WIRTUOZOSTWA W KONTEKŚCIE DEBAT ESTETYCZNYCH Z CZASÓW BEETHOVENA}

Do roku 1800 sam termin „wirtuoz” przybierał wiele znaczeń. Znajdował zastosowanie nawet poza muzyką ${ }^{1}$. Zwykle używany był dla opisania pewnego zakresu muzycznych zajęć, umiejętności, zdolności i zachowań. Na poziomie najbardziej podstawowym mógł oznaczać po prostu profesję muzyczną. Ferdinand Schönfeld do grona wirtuozów zalicza zarówno kompozytorów jak i wykonawców (Jones 107). Tak szeroki zakres „muzycznego wirtuozostwa” sięga nawet do końca XVII wieku, kiedy termin znalazł zastosowanie w niemieckojęzycznym piśmiennictwie w odniesieniu do kompozytorów, teoretyków i wykonawców obdarzonych wyjątkowymi zdolnościami. Wedle Ericha Reimera (61) dopiero od 1730 roku termin ,wirtuoz” był regularnie stosowany w węższym zakresie, odnosząc się do praktykujących muzyków, czyli instrumentalistów i śpiewaków. Jednak ta węższa zakresowo definicja nie została powszechnie zaadaptowana nawet na początku XIX wieku. I dopiero w latach 30. i 40. tegoż stulecia wirtuozostwo zostało skojarzone wyłącznie z wykonawcami (Cvejić 6-17).

Wśród pism dedykowanych kategorii wirtuozostwa na szczególną uwagę zasługują teksty Johanna Karla Friedricha Triesta. To ten organizator życia muzycznego w Szczecinie, nauczyciel muzyki i publicysta wskazywał, że wirtuoz chcący „poruszyć” słuchacza powinien dysponować nie tylko biegłością techniczną, ale i fundamentalną znajomością teorii muzyki, a szczególnie zasad kompozycji. Co więcej, powinien był posiadać jasny obraz estetyczny i psychologiczny utworu, będący rezultatem nie tylko rutyny i „naturalnego zrozumienia”

\footnotetext{
${ }^{1}$ Zagadnieniu temu poświęca całą monografię Paul Metzner (1998).
} 
muzyki, ale też studium i dogłębnej troski o własne wnętrze (Triest 47:760). Zdaniem Triesta (47:760) wszyscy wirtuozi powinni mieć na względzie jeden wyraźny cel: wzbudzenie podziwu i zachwytu. I to Triest (48:770) utrzymywał, że prezentacja muzyki jest nie tylko aktem estetycznym, ale i aktem społecznym, bo (nieprzypadkowa) osobowość wykonawcy wyraziście ją mediuje.

Ferraguto posuwa się w interpretacji zagadnienia wykonawczego jeszcze dalej, korzystając z teorii Pierre'a Bourdieu (1986) i używanych w socjologii terminów kapitału kulturowego i habitusu. Rolą wirtuoza, wedle takich kategorii, staje się przekształcenie posiadanego przez niego kapitału kulturowego, osiągniętego na drodze treningu i doświadczenia - ze stanu „uwewnętrznienia” (habitus wirtuoza tzn. jego wiedza, talenty i mistyka) w "stan obiektywny” (czyli w sprzedawalny utwór muzyczny lub biletowany koncert) (Ferraguto 57). Jeśli zatem każdy utwór muzyczny w pewnym sensie stanowi reprezentację swego autora, to koncert instrumentalny jest szczególnie związany $\mathrm{z}$ habitusem kompozytora-wykonawcy.

\section{ARTYSTYCZNA OSOBOWOŚĆ BEETHOVENA}

Beethoven spędził początkowe lata swej kariery na tournée koncertowych, a podczas występów pianistycznych był zdolny do znaczących wyczynów technicznych. Jego gra prawdopodobnie była wytrzymała i niedokładna (Ferraguto 58). Podziwiano Beethovenowską technikę wykonawczą, ale często to sposób jego „ekspresywnej” interpretacji zasługiwał na słowa szczególnego uznania. W 1791 Carl Ludwig Junker porównał improwizacje Beethovena do improwizacji Abbé Voglera i zauważył, że gra Beethovena bardziej zapada w serce, bo „Beethoven, poza szczególnymi zdolnościami, jest bardziej elokwentny, bardziej wyrazisty i bardziej ekspresywny [...]" (Senner 25). I opinia taka dotyczyła zarówno wykonywanych przez niego wolnych, jak i szybkich części muzyki. Na łamach wydawanego przez Heinricha Philippa Bosslera pisma Musikalische Korrespondenz 13 listopada 1791 roku właśnie Junker opisywał styl gry dwudziestojednoletniego zaledwie Beethovena, kontrastując tę prawdziwie uczuciową, romantyczną i ekspresyjną wypowiedź artystyczną z powierzchownymi sposobami gry innych wirtuozów, stawiając Mistrza z Bonn za swego rodzaju wzór (Sonneck 11). Z taką modelową opinią Beethoven sam się chętnie identyfikował. Uznawał, że ekspresja wykonawcza i wyrazistość gry to coś więcej niż tylko abstrakcyjna idea. 
Zdaniem Ferraguto (60) właśnie kategoria ekspresji dostarcza cennego hermeneutycznego wglądu w koncerty Beethovena z 1806 roku. O wiele więcej $\mathrm{w}$ nich bowiem oznaczeń ekspresyjnych typu dolce, cantabile, espressivo (i różnych ich wariantów), niż we wcześniej skomponowanych utworach. Ponadto w IV Koncercie fortepianowym, oznaczenia dolce i espressivo często współgrają $\mathrm{w}$ partii fortepianu solowego z konstelacją cech muzycznych, określonych przez Ferraguto (61) mianem specyficznej „topiki ekspresywnej” - kontemplatywnej, lirycznej i introspektywnej. Ekspresywność zatem staje się topikalizowana (Ferraguto 62) i można ją uznać za oznakę nowego podejścia do gatunku koncertu.

Ponadto, jeśli zapisany koncert reprezentuje zobiektywizowaną formę $h a$ bitusu wirtuoza, to ten „zamrożony” zobiektywizowany habitus podlega ożywieniu i transformacji w kolejnych aktach wykonawczych (Ferraguto 66). Z tak wytworzonej możliwości, Beethoven zdawał się chętnie korzystać, zaskakując swą publiczność i udoskonalając solową partię swej muzyki w kolejnych prezentacjach.

\section{MOŻLIWOŚCI I OGRANICZENIA INSTRUMENTU}

Pod koniec 1803 roku Beethoven stał się właścicielem nowego typu fortepianu francuskiej firmy Sébastien Erard. W kolejnych dwóch latach jednak już dwukrotnie prosił budowniczego o skonstruowanie fortepianu o lżejszej mechanice, zbliżonej do mechaniki instrumentów szkoły wiedeńskiej. Dysponując od końca lat 90. XVIII wieku fortepianem zbudowanym przez Antona Waltera, do takiej był bowiem przyzwyczajony. Do 1810 roku fortepian Erarda okazał się dla Beethovena bezużyteczny, bo nie nadawał się już do naprawy (Ferraguto 148).

Przez wiele lat przypuszczano, że Beethovenowi nie przypadł do gustu nowy Erard i dlatego nie przedstawiał dla niego większej wartości. Ostatnio jednak badacze zakwestionowali ową hipotezę twierdząc, że początkowo kompozytor był oczarowany nowym instrumentem. I to właśnie nowy Erard dał impulsy dla ważnych utworów z początku XIX wieku (Skowroneck 102).

Maria Rose van Epenhuysen (110-22) odkryła nawet, że fortepian Erarda nie był prezentem paryskiej firmy, lecz instrumentem zamówionym przez samego Beethovena. Wpływ Erarda na muzykę fortepianową Beethovena uwidacznia się w sposób szczególny (od 1803 roku) w zwiększeniu zakresu użytej skali pianistycznej do pięciu i pół oktaw. Ponadto, niektóre Beethovenowskie 
partytury tego okresu w samej notacji muzycznej zdają się bezpośrednio wskazywać na korzystanie z nowego instrumentu.

W drugiej części IV Koncertu fortepianowego wymagane jest użycie specjalnego crescenda pedałowego ${ }^{2}$, efektu brzmieniowego niemożliwego do osiągnięcia na ówczesnych fortepianach wiedeńskich. Beethoven wykazywał spore zainteresowanie nowym sposobem pedalizacji i właśnie dlatego mógł zamówić fortepian z mechanizmem pedałowym z firmy Erarda (Ferraguto 149-59). Ponadto w IV Koncercie, w celach wręcz strategicznych wykorzystany został najwyższy rejestr fortepianu pięcioipółoktawowego. Twórca uczynił to w momentach o szczególnym znaczeniu ekspresyjnym: nie kulminacyjnych, ale lirycznych - wielce charakterystycznych dla tej muzyki. Użycie ekstremów rejestrowych w kompozycjach z okresu Erarda potwierdza Beethovenowską tendencję do poszerzania granic fortepianu i samego pianizmu (Ferraguto 175).

Odkrycia poczynione przez Ferraguto prowadzą do zmiany postrzegania znaczenia instrumentu w twórczości Beethovena. Fortepian, jego możliwości i ograniczenia, determinował do pewnego stopnia sam proces kompozytorski, nie był jedynie „narzędziem” do wykonywania uprzednio napisanej muzyki. Pomijanie tego wątku zubożyć może wyraźnie horyzont, również współczesnych, interpretacji muzyki.

\section{UWAGI KOŃCOWE}

Przyjęcie perspektywy mikrohistorycznej w badaniach muzykologicznych wydaje się inicjatywą interesującą poznawczo. Mikrohistoria stawia bowiem szereg innych pytań, niż czynią to tradycyjne badania muzykologiczne. Skupia swoją uwagę na pojedynczej kompozycji, bada ją w sposób indywidualny i historyczny zarazem. Nie lekceważąc samego tekstu muzycznego uwzględnia kontekst jego czasów: historyczny, społeczny, polityczny i kulturowy. Realizując pragnienie zrozumienia muzyki w sposób nowy i szerszy, nie ignoruje relacji twórcy do konkretnych osób, przedmiotów, miejsc i okoliczności życia. Korzysta z dokonań innych obszarów badawczych, czasem z wypracowanych przez nie pojęć (mediacja, kapitał kulturowy, habitus), a czasem nawet z metodologii.

W refleksji nad IV Koncertem fortepianowym Beethovena inwestygacja mikrohistoryczna okazała się zabiegiem interesująco wzbogacającym i porządkującym dotychczasowy stan wiedzy. Uwzględniła co najmniej kilka nowych obszarów mogących mieć wpływ na przebieg samego procesu twórczego i na finalną

\footnotetext{
${ }^{2}$ Przejścia z jednej struny przez dwie do trzech strun.
} 
koncepcję omawianego tu dzieła. Były nimi, przypomnijmy, technika pianistyczna twórcy w powiązaniu z oczekiwaniami współczesnych mu słuchaczy, kategoria wirtuozostwa w kontekście ówczesnych debat estetycznych, artystyczna osobowość kompozytora oraz możliwości i ograniczenia instrumentu pozostającego do jego dyspozycji w procesie komponowania. Wyniki analiz przeprowadzonych przez Ferraguto - choć w niektórych miejscach zbieżne ze znanymi już analizami kontekstowymi czy badaniami recepcji, a i w niniejszym tekście zrelacjonowane w sposób skrótowy - zachęcają do poszukiwania dalszych metod badawczych i do odkrywania, być może, kolejnych horyzontów interpretacyjnych.

\section{BIBLIOGRAFIA}

Bourdieu, Pierre. „The Forms of Capital”. Handbook of Theory and Research for the Sociology of Education, red. John G. Richardson, Greenwood Press, 1986, ss. 241-258.

Cvejić, Žarko. The Virtuoso as Subject: The Reception of Instrumental Virtuosity, c. 1815-c. 1850. Cambridge Scholars Publishing, 2016.

Czerny, Carl. On the Proper Performance of all Beethoven's Works for the Piano, red. Paul BaduraSkoda, Universal Edition, 1970.

Darnton, Robert. The Great Cat Massacre and Other Episodes in French Cultural History. Basic Books, 1984.

Davis, Natalie Zemon. The Return of Martin Guerre. Harvard University Press, 1983.

Epenhuysen, Maria Rose van. „Beethoven and His «French Piano»: Proof of Purchase”. MusiqueImages-Instruments, $\mathrm{nr} 7,2005$, ss. 110-122.

Everist, Mark. Music Drama at the Paris Odéon, 1824-1828. U of California P, 2002.

Felski, Rita. „Context Stinks!”. New Literary History, t. 42, nr 4, 2011, ss. 573-591.

Ferraguto, Mark. Beethoven 1806. Oxford UP, 2019. AMS Studies in Music.

Forbes, Elliot. Thayer's Life of Beethoven, t. 1. Princeton UP, 1964.

Ginzburg, Carlo. Il formaggio e i vermi. Il cosmo di un mugnaio del '500. Einaudi, 1976.

Hennion, Antoine. „Music and Mediation: Towards a new Sociology of Music”. The Cultural Study of Music: A Critical Introduction, red. Martin Clayton et al., Routledge, 2003, ss. 80-91.

Jander, Owen. „Beethoven's «Orpheus in Hades»: The «Andante con moto» of the Fourth Piano Concerto". 19th-Century Music, t. 8, nr 3, 1985, ss. 195-212.

Jones, David Wyn. Music in Vienna: 1700, 1800, 1900. The Boydell Press, 2016.

Kinderman, William. Beethoven. Oxford UP, 2009.

Knittel, K. M. „The Construction of Beethoven”. The Cambridge History of Nineteenth-Century Music, red. Jim Samson, Cambridge UP, 2001, ss. 118-510.

Latour, Bruno. Reassembling the Social: An Introduction to Actor-Network Theory (Oxford UP, 2005).

Le Roy Ladurie, Emmanuel. Montaillou, village occitan de 1294 à 1324. Éditions Gallimard, 1975. 
Levi, Giovanni. Centro e periferia di uno Stato assoluto. Tre saggi su Piemonte e Liguria in età moderna. Rosenberg \& Sellier, 1985.

Levitz, Tamara. Modernist Mysteries: Perséphone. Oxford UP, 2012.

Madrid, Alejandro L. „Why Music and Performance Studies? Why Now? An Introduction to the Special Issue". Revista Transcultural de Música, nr 13, 2009.

McVeigh, Simon. „Concerto of the Individual”. The Cambridge History of Eighteenth-Century Music, red. Simon P. Keefe, Cambridge UP, 2009, ss. 583-612.

Metzner, Paul. Crescendo of the Virtuoso: Spectacle, Skill, and Self-Promotion in Paris during the Age of Revolution. U of California P, 1998.

Reimer, Erich. „Der Begriff des wahren Virtuosen in der Musikästhetik des späten 18. und frühen 19. Jahrhunderts". Basler Jahrbuch für historische Musikpraxis: Eine Veröffentlichung der Schola Cantorum Basiliensis an der Musik-Akademie der Stadt Basel, nr 20, 1996, ss. 61-72.

Schmelz, Peter J. „«Shostakovich» Fights the Cold War: Reflections from Great to Small”. Journal of Musicological Research, t. 34, nr 2, 2015, ss. 91-140.

Senner, Wayne M., et al, redaktorzy. The Critical Reception of Beethoven's Compositions by His German Contemporaries. U of Nebraska P, 2001.

Skowroneck, Tilman. „Beethoven's Erard Piano: Its Influence on His Compositions and on Viennese Fortepiano Building”. Early Music, t. 30, nr 4, 2002, ss. 522-538.

Skowroneck, Tilman. Beethoven the Pianist. Cambridge UP, 2010.

Small, Christopher. Musicking: The Meanings of Performing and Listening. Wesleyan UP, 1998.

Oskar Sonneck, redaktor i thumacz. Beethoven: Impressions by His Contemporaries. Dover, 1967.

Steinberg, Michael. The Concerto: A Listener's Guide. Oxford UP, 2000.

Strunk, Oliver, redaktor. Source Readings in Music History. Norton, 1950.

Triest, Johann K. F. „Abhandlung: Über reisende Virtuosen”. Allgemeine musikalische Zeitung, t. 4, nr 46, 1802, szp. 737-749; nr 47, 1802, szp. 753-760; nr 48, 1802, szp. 769-775.

\section{KONCERT FORTEPIANOWY LUDWIGA VAN BEETHOVENA W ODCZYTANIU MIKROHISTORYCZNYM}

Streszczenie

Artykuł stanowi próbę wskazania nowych obszarów w badaniu muzyki Beethovena (IV Koncert fortepianowy), które można rozwinąć, przenosząc na grunt muzykologii perspektywę mikrohistoryczną. Rozpoczyna się od krótkiej refleksji nad przydatnością i dotychczasową obecnością mikrohistorii w badaniach nad sztuką dźwięku. Następnie autorka referuje rezultaty analiz poczynionych przez Marka Ferraguto, skupiając się na takich zagadnieniach, jak technika pianistyczna Beethovena w powiązaniu z oczekiwaniami współczesnych mu słuchaczy, kategoria wirtuozostwa w kontekście ówczesnych debat estetycznych, artystyczna osobowość kompozytora oraz możliwości i ograniczenia instrumentu pozostającego do jego dyspozycji w procesie komponowania.

Slowa kluczowe: Beethoven; IV Koncert fortepianowy; mikrohistoria; habitus; Erard. 


\section{A MICROHISTORICAL READING \\ OF LUDWIG VAN BEETHOVEN'S PIANO CONCERTO NO. 4}

S u m m a r y

This article is an attempt to indicate new areas in the study of Beethoven's music (Fourth Piano Concerto), which can be developed by applying a microhistorical perspective to musicology. It begins with a short reflection on the usefulness and presence of microhistories in research on the art of sound. The author then presents the results of Mark Ferraguto's analyses, focusing on such issues as Beethoven's piano technique in relation to the expectations of his contemporary listeners; the category of virtuosity in the context of the aesthetic debates of the time; the composer's artistic personality; and the possibilities and limitations of the instrument at his disposal in the process of composition.

Keywords: Beethoven; Fourth Piano Concerto; microhistory; habitus; Erard. 